\title{
Effect of colouring green stage zirconia on the adhesion of veneering ceramics with different thermal expansion coefficients
}

\author{
Guliz Aktas $^{1}$, Erdal Sahin ${ }^{1}$, Pekka Vallittu ${ }^{2}$ Mutlu Özcan ${ }^{3}$ and Lippo Lassila ${ }^{2}$
}

This study evaluated the adhesion of zirconia core ceramics with their corresponding veneering ceramics, having different thermal expansion coefficients (TECs), when zirconia ceramics were coloured at green stage. Zirconia blocks $(\mathrm{N}=240 ; 6 \mathrm{~mm} \times 7 \mathrm{~mm} \times 7 \mathrm{~mm})$ were manufactured from two materials namely, ICE Zirconia (Group 1) and Prettau Zirconia (Group 2). In their green stage, they were randomly divided into two groups. Half of the specimens were coloured with colouring liquid (shade A2). Three different veneering ceramics with different TEC (ICE Ceramic, GC Initial Zr and IPS e.max Ceram) were fired on both coloured and non-coloured zirconia cores. Specimens of high noble alloys (Esteticor Plus) veneered with ceramic (VM 13) $(n=16)$ acted as the control group. Core-veneer interface of the specimens were subjected to shear force in the Universal Testing Machine $\left(0.5 \mathrm{~mm} \cdot \mathrm{min}^{-1}\right)$. Neither the zirconia core material $(P=0.318)$ nor colouring $(P=0.188)$ significantly affected the results (three-way analysis of variance, Tukey's test). But the results were significantly affected by the veneering ceramic $(P=0.000)$. Control group exhibited significantly higher mean bond strength values $(45.7 \pm 8) \mathrm{MPa}$ than all other tested groups $((27.1 \pm 4.1)-(39.7 \pm 4.7)$ and $(27.4 \pm 5.6)-(35.9 \pm 4.7) \mathrm{MPa}$ with and without colouring, respectively) $(\boldsymbol{P}<0.001)$. While in zirconia-veneer test groups, predominantly mixed type of failures were observed with the veneering ceramic covering $<1 / 3$ of the substrate surface, in the metal-ceramic group, veneering ceramic was left adhered $>1 / 3$ of the metal surface. Colouring zirconia did not impair adhesion of veneering ceramic, but veneering ceramic had a significant influence on the core-veneer adhesion. Metal-ceramic adhesion was more reliable than all zirconia-veneer ceramics tested. International Journal of Oral Science (2013) 5, 236-241; doi:10.1038/ijos.2013.66; published online 25 October 2013

Keywords: adhesion; bond strength; colouring; thermal expansion coefficient; zirconia

\section{INTRODUCTION}

Metal-ceramics have long been widely used for the fabrication of fixed dental prosthesis (FDP). The increase in patients' demands for aesthetics and awareness of aesthetic restorative materials made all ceramic restorations more popular. Today, many types of all-ceramic core materials are available with different crystalline contents. ${ }^{1}$ Among high strength ceramics, yttrium oxide-stabilized tetragonal zirconia polycrystals (hereon: zirconia) present greater fracture strength than other ceramic core materials and conventional ceramics. For this reason, they have been the centre of the interest as a core material for FDPs during the last decade..$^{2-3}$

The technological developments of machining zirconia ceramics have created a growing interest in the use of zirconia ceramics for both anterior and posterior FDPs. During fabrication of FDPs, different methods can be used such as milling only the framework of the FDP or milling the full anatomical contour of the FDP from zirconia blocks, where only the buccal surfaces are veneered. ${ }^{3}$ In general, in order to achieve a more aesthetically pleasing appearance, the framework of allceramic restorations should be veneered with a ceramic that is more translucent. ${ }^{4}$ Clinical success of an FDP does not only depend on the strength of the framework, but also on the adhesion of the veneering ceramic on the core material.

Current clinical evidence on the zirconia FDPs present chipping rate up to $15.2 \%$ in a relatively short service of about $35.1( \pm 13.8)$ months ${ }^{5-7}$ that is higher than with metal-ceramics. ${ }^{8-9}$ Factors associated with this problem can include: lack of proper framework geometry, inadequate framework support, fatigue phenomenon, internal ceramic defects, lack of occlusal stability, patient-related factors and material properties such as incompatibility of the thermal expansion coefficients (TECs) between the framework and the veneering ceramic and insufficient adhesion. ${ }^{10-11}$ Even though these aspects have been studied and optimized, clinical chipping incidence is still being observed.

It has been recently postulated that in addition to all possible factors for chipping, colouring may also affect the adhesion of veneering ceramic on zirconia. ${ }^{12-13}$ Low contrast ratio of zirconia core can influence the final optical appearance of the veneered FDP negatively. In order to obtain more aesthetic restorations, different colouring

${ }^{1}$ Department of Prosthodontics, Faculty of Dentistry, Hacettepe University, Ankara, Turkey; ${ }^{2}$ Department of Biomaterials Science and Turku Clinical Biomaterials Centre,

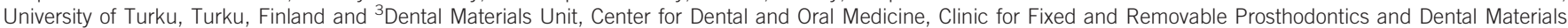
Science, University of Zürich, Zürich, Switzerland

Correspondence: Dr G Aktas, Department of Prosthodontics, Faculty of Dentistry, Hacettepe University, Ankara 06100, Turkey

E-mail: g_emul@yahoo.com

Received 12 February 2012; accepted 19 November 2012 
techniques have been proposed for zirconia core ceramics. ${ }^{12-13}$ One of this technique is subjecting the zirconia surface to colouring agents before sintering. Limited data are available on the colouring liquids and their effect on core-ceramic veneer bonding. ${ }^{13-14}$

The objectives of this study therefore were to (i) assess the bond strengths of non-coloured and coloured zirconia core ceramics veneered with their corresponding veneering ceramics, having different TECs and compare it to metal-ceramic and (ii) analyse the failure types after debonding. The null hypothesis tested was that the colouring agents would not affect the shear bond strength of veneering ceramics to zirconia.

\section{MATERIALS AND METHODS}

The types, brands, manufacturers, compositions of the core materials and veneering ceramics, and TECs of the ceramics used in this study are listed in Table 1. Two different partially stabilized green stage zirconia core materials, one metal core material and four different veneering ceramics were used in this study.

\section{Preparation of the zirconia core specimens}

Zirconia blocks $(N=240 ; 6 \mathrm{~mm} \times 7 \mathrm{~mm} \times 7 \mathrm{~mm})$ were manufactured from two materials namely, ICE Zirconia and Prettau Zirconia. In their green stage, their surfaces were flattened with 800, 1 200, 2400 and 4000 silicon carbide grinding papers in sequence (Struers, Copenhagen, Denmark) for $15 \mathrm{~s}$ in a polishing machine (Struers RotoPol 11; Struers A/S, Rodovre, Denmark). After grinding procedures, half of each group's specimens (60 ICE Zirconia and 60 Prettau Zirconia) were sintered in a sintering oven (Keramikofen 1500, Zirkonzahn, Taufers, Italy) according to the manufacturer's recommendations using corresponding sintering programs. The other half of each group's specimens was coloured with colouring liquid (Shade A2). For this, zirconia specimens were dipped into the colouring liquid with plastic pliers for $3 \mathrm{~s}$ and dried under a warming lamp (Zirkonlampe 250; Zirkonzahn, Taufers, Italy) for $30 \mathrm{~min}$ according to the manufacturer's recommended time. After this procedure, coloured specimens were sintered in the same sintering oven with the corresponding sintering programs.
After sintering procedures, all specimens were air-abraded with $50 \mu \mathrm{m}$ aluminium oxide $\left(\mathrm{Al}_{2} \mathrm{O}_{3}\right)$ particles at 3.5 bar pressure for $20 \mathrm{~s}$ with a nozzle distance of approximately $10 \mathrm{~mm}$ from the surface (Sandstorm Expert, Vaniman, Fallbrook) to increase the surface roughness and improve the adhesion of veneering ceramics.

\section{Preparation of metal core specimens}

Rectangular ( $6 \mathrm{~mm} \times 7 \mathrm{~mm} \times 7 \mathrm{~mm}$ ) high noble metal alloy (Esteticor Plus; Cendres+Metaux SA, Biel, Switzerland) specimens $(N=20)$ were cast according to the manufacturer's recommendations. They were then air-abraded with the same parameters used for the zirconia specimens. Specimens were fired in the ceramic oven at $960{ }^{\circ} \mathrm{C}$ for $5 \mathrm{~min}$ according to the manufacturer's recommendations in order to form oxide layer before veneering with ceramic material.

\section{Veneering procedures}

Both zirconia and metal core specimens were cleaned with pressure steam (Plyno, Via Lipparini, Bologna, Italy) for $1 \mathrm{~min}$ and air-dried with air-spray prior to applying veneering ceramic materials. In the case of zirconia core specimens, a thin layer of ceramic liner was applied. During the ceramic veneering procedure, a custom-made mould was used to apply the veneering ceramic. Each veneering ceramic powder was mixed with the corresponding manufacturer's liquid. The veneering ceramics were vibrated and condensed in stainless steel separable mould (diameter: $2.8 \mathrm{~mm}$, height: $3 \mathrm{~mm}$ ) (Figure 1). Excess liquid was absorbed with a tissue. Firing of the specimens was performed in a ceramic oven according to the respective manufacturer's recommendations. Three different veneering ceramics with different TEC (ICE Ceramic, GC Initial Zr, and IPS e.max Ceram) were fired on both non-coloured and coloured zirconia cores. Specimens of high noble alloys were veneered with a feldspar ceramic (VM 13) and acted as the control group.

\section{Shear bond strength test}

After veneering ceramic materials were fired on the core materials, the diameter of each veneered specimen was assured with a digital micrometer (Mitutoyo, Andover, UK). Test specimens were stabilized with a

Table 1 The types, brands, manufacturers, compositions of the core materials and veneering ceramics and TECs of the ceramics used in this study

Materials (manufacturer) Compositions

Core materials

Y-TZP

ICE Zirconia (Zirkonzahn, Taufers, Italy)

Prettau Zirconia (Zirkonzahn, Taufers, Italy)

Metal

High noble metal alloy (Esteticor Plus, Cendres + Metaux SA, Biel, Switzerland)

Veneering ceramics

GC Initial Zr (GC Europe N.V., Interleuvenlaan, Leuven, Belgium)

IPS e.max Ceram (Ivoclar Vivadent AG, Schaan, Liechtenstein)

ICE Ceramic (Zirkonzahn, Taufers, Italy)

VM 13 (Vita Zahnfabrik, Bad Säckingen, Germany)

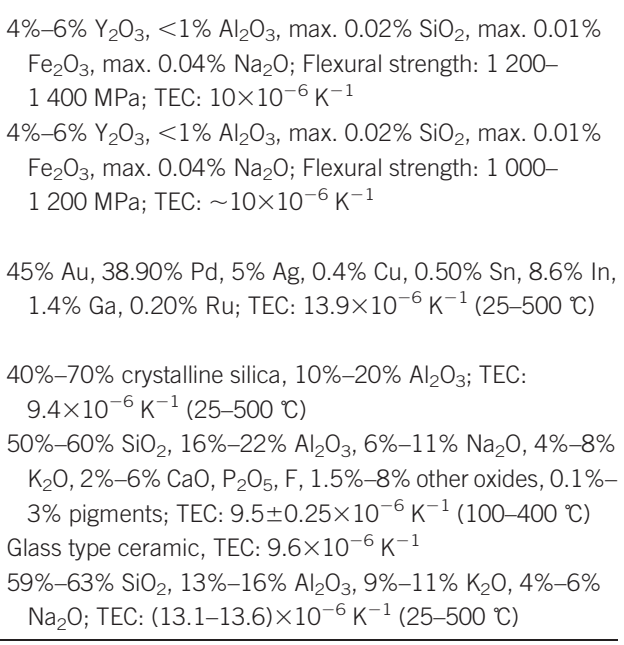

TEC, thermal expansion coefficient; Y-TZP, yttrium oxide-stabilized tetragonal zirconia polycrystal. 


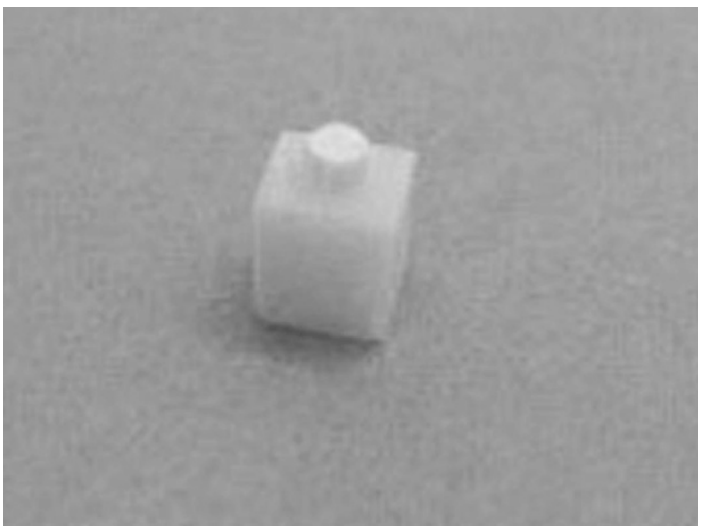

Figure 1 Veneering ceramic baked on the framework zirconia block.

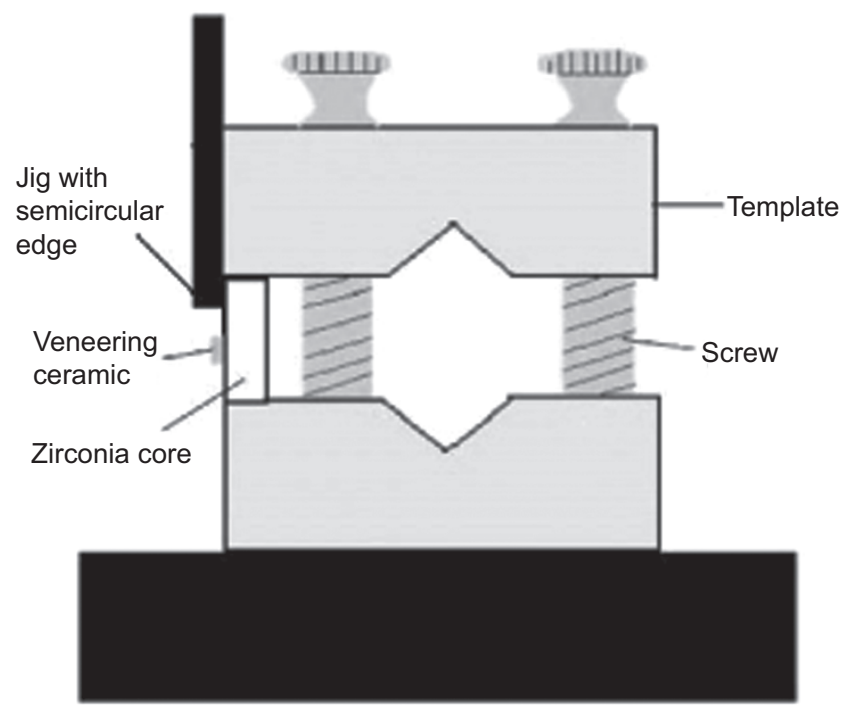

Figure 2 Schematic drawing of the fixation device where the ceramic block was clamped.

custom made simple block clamp system in order to achieve shear force at an angle of $90^{\circ}$ towards the core-ceramic interface (Figure 2). The load was applied with a jig having a semicircular edge. The edge of the jig was positioned as close as possible to the core side of the core-ceramic interface. Shear bond strength test was performed in the Universal Testing Machine (Lloyd-LRX; Lloyd Instruments, Fareham, UK) at a crosshead speed of $0.5 \mathrm{~mm} \cdot \mathrm{min}^{-1}$. Bond strength was calculated dividing the load at debonding and the surface area of the core-veneer interface with a software (Nexygen; Lloyd Instruments, Fareham, UK).
Failure type analysis

After debonding, specimen surfaces were analysed using optical microscopy (Stereomicroscope, Wild M3B, Heerbrugg, Switzerland) at $\times 40$ magnification and scanning electron microscope (SEM) (JEOL 5500 ; JEOL, Tokyo, Japan) at $\times 35$ and $\times 250$ magnification to characterize the failure modes. After evaluating all SEM images, the failure types were defined as (i) ADHES: adhesive failure between the veneering ceramic and the framework with no veneering ceramic remnants left adhered; (ii) MIXED1: Cohesive failure of the veneering ceramic with $<1 / 3$ left adhered on the framework material; (iii) MIXED2: cohesive failure of the veneering ceramic with $>1 / 3$ left adhered on the framework material; and (iv) COHES-core: cohesive failure of the framework material.

\section{Statistical analysis}

Statistical analysis was performed using SPSS 11.0 software for Windows (SPSS Inc., Chicago, IL, USA). Bond strength data ( $\mathrm{MPa})$ were submitted to three-way analysis of variance with the bond strength as the dependent variable and core material type (three levels; ICE Zirconia, Prettau Zirconia and noble alloy), veneering ceramics (three levels; ICE Ceramic, GC Initial Zr and IPS e.max Ceram) and colouring (two levels; with and without) as independent variables. Multiple comparisons were made using Tukey's test. $P$ values less than 0.05 were considered to be statistically significant in all tests.

\section{RESULTS}

Neither the zirconia core material $(P=0.318)$ nor colouring $(P=$ $0.188)$ significantly affected the results. But the results were significantly affected by the veneering ceramic $(P=0.000)$. Interaction terms were not significant $(P=0.484, P=0.280$ and $P=0.467$ ) (Table 2).

Control group (metal core-ceramic veneer) exhibited significantly higher mean bond strength values $((45.7 \pm 8) \mathrm{MPa})$ than all other tested groups $((27.1 \pm 4.1)-(39.7 \pm 4.7)$ and $(27.4 \pm 5.6)-(35.9 \pm 4.7) \mathrm{MPa}$ with and without colouring, respectively) $(P<0.001)$ (Figure 3$)$.

The multiple comparison with Tukey's test revealed no significant difference between ICE Ceramic veneering material and GC Initial Zr veneering material with and without colouring of this zirconia material, respectively $(P=0.642)$. In combination with this zirconia type, IPS e.max Ceram exhibited significantly lower bond strength values $(27.4-27.1 \mathrm{MPa})$ than those of GC Initial $\mathrm{Zr}$ and ICE Ceramic $(P<0.001)$.

The highest mean bond strength value was for coloured Prettau Zirconia core when it was veneered with GC Initial Zr veneering ceramic material (39.78 MPa). As for ICE Zirconia core, there were no significant differences between GC Initial $\mathrm{Zr}$ and ICE Ceramic veneering ceramics with and without colouring, respectively $(P=0.642)$. Also, in combination with this zirconia type, IPS e.max Ceram veneering ceramic also exhibited significantly lower bond

Table 2 Results of three-way ANOVA and Tukey's test

\begin{tabular}{|c|c|c|c|c|c|}
\hline Source & Sum of squares & Degree of freedom & Mean square & $F$ & $P$ \\
\hline Framework material & 32.976 & 1 & 32.976 & 1.000 & 0.318 \\
\hline Veneering ceramic & 3758.892 & 2 & 1879.446 & 56.989 & 0.000 \\
\hline Colouring & 57.446 & 1 & 57.446 & 1.742 & 0.188 \\
\hline Framework*Veneering ceramic & 48.022 & 2 & 24.011 & 0.728 & 0.484 \\
\hline Framework*Colouring & 38.615 & 1 & 38.615 & 1.171 & 0.280 \\
\hline Veneering ceramic*Colouring & 50.451 & 2 & 25.226 & 0.765 & 0.467 \\
\hline Error & 7519.193 & 228 & 32.979 & & \\
\hline Total & 278925.444 & 240 & & & \\
\hline
\end{tabular}

ANOVA, analysis of variance. 


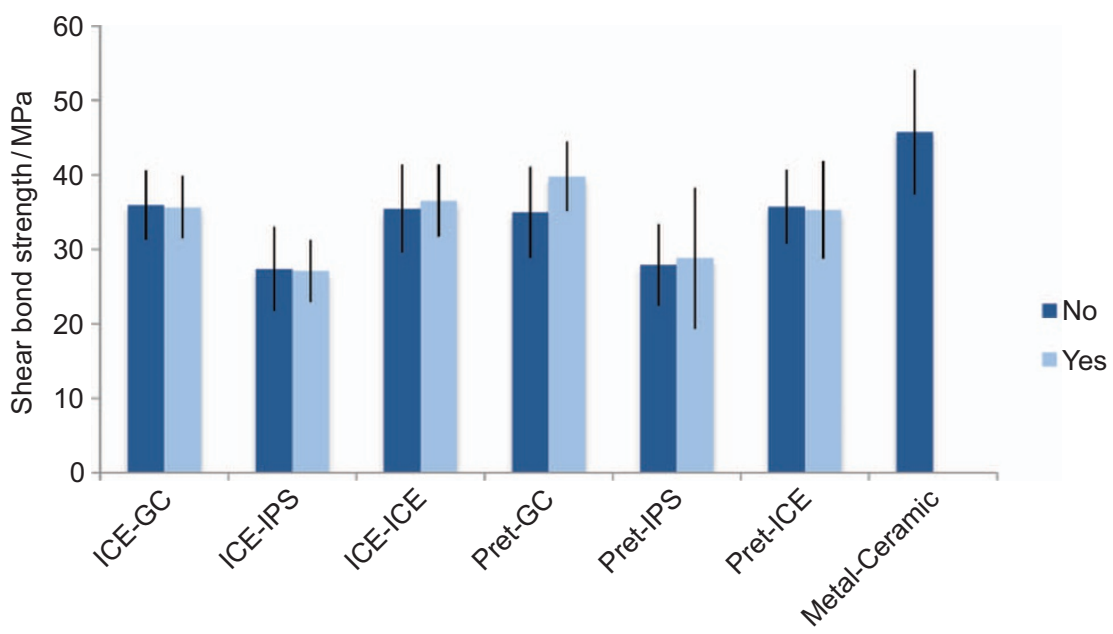

Figure 3 Mean and standard deviations of framework-veneering ceramic bond strength with and without colouring of the framework.
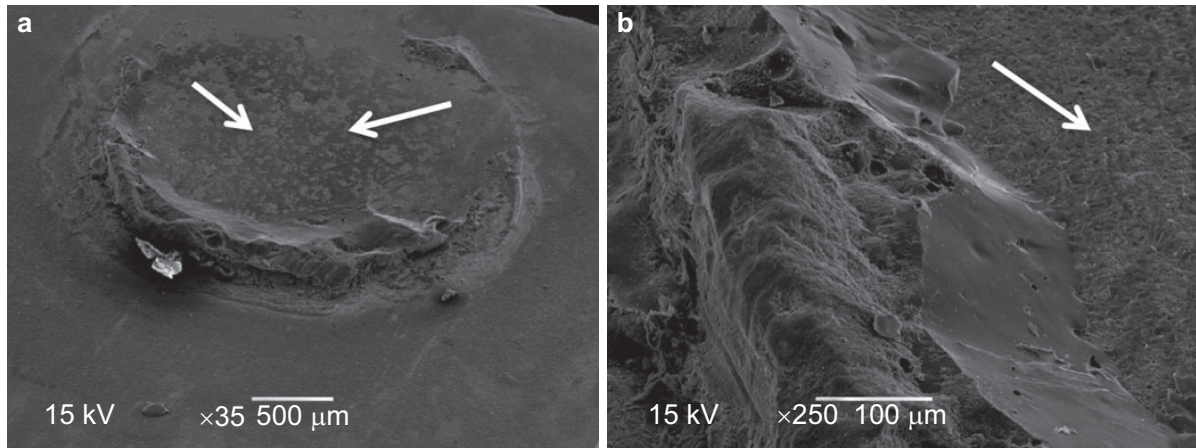

Figures 4 Representative SEM image of MIXED2 type of failure (cohesive failure of the veneering ceramic with $>1 / 3$ left adhered on the framework material). (a) Magnification $\times 35$; (b) magnification $\times 250$. Note the remnants of the veneering material on the zirconia substrate indicated by arrows. SEM, scanning electron microscope.

strength values than those of GC Initial $\mathrm{Zr}$ and ICE Ceramic $(P<0.001)$.

While in zirconia-veneer test groups, predominantly mixed type of failures were observed with the veneering ceramic covering $<1 / 3$ of the substrate surface, in the metal-ceramic group, veneering ceramic was left adhered $>1 / 3$ of the metal surface (Table 3 ).

The SEM evaluation revealed a thin layer of veneering ceramic material on the core surface of all tested groups (Figure 4).

\section{Table 3 Distribution of the frequencies of failure types}

Type of failure

\begin{tabular}{|c|c|c|c|c|c|}
\hline \multirow[b]{2}{*}{ Framework-veneer } & \multirow[b]{2}{*}{ Colouring } & \\
\hline & & ADHES & MIXED1 (veneer $<1 / 3$ ) & MIXED2 (veneer >1/3) & COHES-core \\
\hline ICE-GC & No & 0 & 20 & 0 & 0 \\
\hline ICE-GC & Yes & 0 & 20 & 0 & 0 \\
\hline ICE-IPS & No & 4 & 16 & 0 & 0 \\
\hline ICE-IPS & Yes & 3 & 17 & 0 & 0 \\
\hline ICE-ICE & No & 0 & 20 & 0 & 0 \\
\hline ICE-ICE & Yes & 0 & 20 & 0 & 0 \\
\hline Pret-GC & No & 0 & 20 & 0 & 0 \\
\hline Pret-GC & Yes & 0 & 20 & 0 & 0 \\
\hline Pret-IPS & No & 4 & 16 & 0 & 0 \\
\hline Pret-IPS & Yes & 4 & 16 & 0 & 0 \\
\hline Pret-ICE & No & 0 & 20 & 0 & 0 \\
\hline Pret-ICE & Yes & 0 & 20 & 0 & 0 \\
\hline Metal-ceramic & - & 0 & 0 & 20 & 0 \\
\hline
\end{tabular}

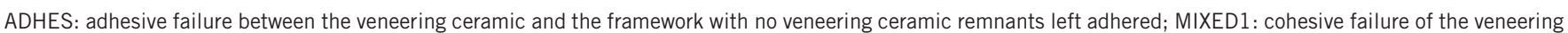

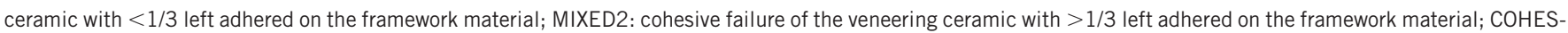
core: cohesive failure of the framework material. 


\section{DISCUSSION}

The present study investigated the effect of colouring on shear bond strength of three veneering ceramics having different TECs to two zirconia core materials. Since zirconia is a white material, colour match of the veneered-zirconia FDPs can be improved when zirconia core material is coloured with a colouring liquid. There was no statistically significant effect of colouring liquid when zirconia materials were coloured in their green state on the adhesion of veneering ceramics. Thus, the null hypothesis was accepted.

Various test methods have been suggested to investigate the bond strength between core and veneering ceramics. ${ }^{13,15-18}$ Of these methods, microtensile test creates more uniform stress distribution at the adhesive interface, but with this test method, during specimen preparation, the cutting process to obtain beam specimens may introduce cracks at the adhesive zone. On the other hand, shear bond strength test used in this study, allows quick ranking of material combinations or systems. Yet, opposite to microtensile bond test, it is claimed that this test method may produce more non-uniform stresses at the interface. Limited data are available regarding the effect of the application of colouring liquid on veneer bonding. ${ }^{14}$ With this test method, our results did not show significant effect of colouring that is contrary to the findings of a previous study, where colouring was found to decrease adhesion of veneering ceramics to zirconia compared to non-coloured ones. ${ }^{14}$ One possible explanation for this difference could be attributed to the test method where in the latter microtensile test was used. Also in that study, pre-test failures were not considered in the statistics, which could have affected the results. If they were considered as $0 \mathrm{MPa}$, the results could have been affected. ${ }^{19-20}$

In a previous study, the distribution of colouring pigments was observed around grain boundaries of zirconia. ${ }^{13}$ The slow crack growth had the tendency to travel in this region. The presence of these pigments in this region caused zirconia not to show evidence of transformation activity of the crack in the fractured specimens. The non-transformation at the crack tip zone was considered for the reduction in the fracture toughness and lower $R$-curve behaviour of the zirconia with pigments.

In dental literature, the shear bond strength values of veneering ceramics to their core ceramics ranged between 16 and $42 \mathrm{MPa},{ }^{14-16,19}$ whereas our results ranged between 27 and $40 \mathrm{MPa}$. Certainly, the differences between this study and those of others may be due to variation in the bonded area or the TEC of the materials used. ${ }^{19}$

According to the results of this study, mean bond strength did not show significant difference between the two zirconia materials tested. Also, none of the zirconia and veneering combinations exceeded the values attained in the metal-ceramic group. The results of metalceramic combinations are in compliance with some of the previous studies. ${ }^{18,21}$ In metal-ceramic combinations, minimum bond strength of $25 \mathrm{MPa}$ was reported in Schwickerath crack initiation test, ${ }^{22}$ which is lower than that obtained in this study (45.72 MPa). To date, adequate bond strength and the test standardisation for zirconia core and its veneering ceramic have not been clarified in the literature. The adhesion between metal and veneering ceramic is primarily based on the mechanical interlocking between the ceramic and the alloy, van der Walls forces and the chemical bonds between the ceramic and the oxide layer. ${ }^{23}$ Also, the effect of TEC of the core and the veneer ceramics on the bonding between the two has been previously discussed. ${ }^{19,24}$ But the bonding mechanisms of veneering ceramics to zirconia surfaces are not clear to date.

In this study, significant differences were found between the bond strengths of IPS e-max Ceram and two other veneering ceramics onto both ICE Zirconia and Prettau Zirconia core materials. This result emphasizes that the veneering ceramic may play a more substantial role on the adhesion to zirconia. Since the TECs of the zirconia materials were comparable, wettability of the IPS e-max Ceram or the internal residual stresses during cooling may be responsible for the variation between the performances of this ceramic onto both zirconia materials. It should also be noted that only with this veneering ceramic, some adhesive failures were noted with and without colouring of the zirconia, indicating some change at the interface when this veneering ceramic was used. Therefore, the use of veneer ceramiczirconia combinations should be tested before clinical application. While ICE Zirconia could be veneered with glass ceramics, Prettau Zirconia has been recently been introduced also for monolithic applications in an attempt to decrease the chipping possibility. Thus, Prettau Zirconia could only be coloured and veneering the buccal or labial surface of the restoration especially for implant supported FDPs may be advantageous because of higher occlusal load. To the authors' prime best knowledge, no information is available when it is used in combination with veneering ceramics. Since zirconia materials did not significantly affect the results, Prettau Zirconia could also be used in combination with veneering ceramics.

In all groups, specimens showed mainly mixed type of failures, but under the stereomicroscope and SEM, residual layer of ceramic with porosities and large flaws were also observed after debonding. Further analyses are needed to identify whether these were colour ceramic components or not. Visual observation indicated that this residual layer seemed to be the colouring ceramic, but further chemical analyses are needed to verify this finding.

From clinical point of view, considering both the bond strength and the failure types, zirconia-veneer combinations did not reach the state of metal-ceramic combinations. Therefore, their indication could still not be considered ideal for load-bearing areas.

\section{CONCLUSION}

From this study, the following could be concluded:

(i) Colour shading of green stage zirconia did not affect the shear bond strength of the veneering ceramic to this substrate with both zirconia materials tested.

(ii) Veneering ceramic type with different TECs significantly affected the adhesion on the zirconia.

(iii) Considering both the bond strength and the failure types, metalceramic adhesion was more reliable than all zirconia-veneer ceramic combinations.

\section{ACKNOWLEDGEMENTS}

This study was part of the PhD work of the first author. Part of this study has been presented at the Thirty-fifth European Prosthodontic Association, 29 September-1 October 2011, Bern, Switzerland.

1 Conrad HJ, Seong WJ, Pesun IJ. Current ceramic materials and systems with clinical recommendations: a systematic review. J Prosthet Dent 2007; 98(5): 389-404.

2 Manicone PF, Rossi lommetti P, Raffaelli L. An overview of zirconia ceramics: basic properties and clinical applications. J Dent 2007; 35(11): 819-826.

3 Denry I, Kelly JR. State of the art of zirconia for dental applications. Dent Mater2008; 24(3): 299-307.

4 Sundh A, Molin M, Sjogren G. Fracture resistance of yttrium oxide partially-stabilized zirconia all-ceramic bridges after veneering and mechanical fatigue testing. Dent Mater 2005; 21(5): 476-482.

5 Vult von Steyern P, Carlson P, Nilner K. All-ceramic fixed partial dentures designed according to the DC-Zirkon technique. A 2-year clinical study. J Oral Rehabil 2005, 32(3): 180-187. 
6 Sailer I, Feher A, Filser $\mathrm{F}$ et al. Prospective clinical study of zirconia posterior fixed partial dentures: 3-year follow-up. Quintessence Int 2006; 37(9): 685-693.

7 Sailer I, Feher A, Filser F et al. Five-year clinical results of zirconia frameworks for posterior fixed partial dentures. Int J Prosthodont 2007; 20(4): 383-388.

8 Walton TR. An up to 15-year longitudinal study of 515 metal-ceramic FPDs: Part 1. Outcome. Int J Prosthodont 2002; 15(5): 439-445.

9 Reitemeier B, Hansel K, Kastner $\mathrm{C}$ et al. Metal-ceramic failure in noble metal crowns: 7 -year results of a prospective clinical trial in private practices. Int $\mathrm{J}$ Prosthodont 2006; 19(4): 397-399.

10 de Jager N, Pallav P, Feilzer AJ. The influence of design parameters on the FEAdetermined stress distribution in CAD-CAM produced all-ceramic dental crowns. Dent Mater 2005; 21(11): 242-251.

11 White SN, Miklus VG, McLaren EA et al. Flexural strength of a layered zirconia and porcelain dental all-ceramic system. J Prosthet Dent 2005; 94(2): 125-131.

12 Heffernan MJ, Aquilino SA, Diaz-Arnold AM et al. Relative translucency of six all-ceramic systems. Part II: core and veneer materials. J Prosthet Dent 2002; 88(1): 10-15.

13 Aboushelib MN, de Jager N, Kleverlaan CJ et al. Microtensile bond strength of different components of core veneered all-ceramic restorations. Dent Mater 2005; 21(10): 984-991.

14 Aboushelib MN, Kleverlaan CJ, Feilzer AJ. Effect of zirconia type on its bond strength with different veneer ceramics. J Prosthodont 2008; 17(7): 401-408.

15 Al-Dohan HM, Yaman P, Dennison JB et al. Shear strength of core-veneer interface in bi-layered ceramics. J Prosthet Dent 2004; 91(4): 349-355.

16 Dündar $\mathrm{M}$, Özcan $\mathrm{M}$, Cömlekoglu $\mathrm{E}$ et al. Bond strengths of veneering ceramics to reinforced ceramic core materials. Int J Prosthodont 2005; 18(1): 71-72.

17 Guess PC, Kulis A, Witkowski S et al. Shear bond strengths between different zirconia cores and veneering ceramics and their susceptibility to thermocycling. Dent Mater 2008; 24(11): 1556-1567.
18 Fischer J, Stawarczyk B, Sailer I et al. Shear bond strength between veneering ceramics and ceria-stabilized zirconia/alumina. J Prosthet Dent 2010; 103(5): 267-274.

19 Dündar M, Özcan M, Gökçe B et al. Comparison of two bond strength testing methodologies for bilayered all-ceramics. Dent Mater 2007; 23(5): 630-636.

20 Brentel AS, Özcan M, Valandro LF et al. Microtensile bond strength of a resin cement to feldpathic ceramic after different etching and silanization regimens in dry and aged conditions. Dent Mater 2007; 23(11): 1323-1331.

21 Ashkanani HM, Raigrodski AJ, Flinn BD et al. Flexural and shear strengths of $\mathrm{ZrO}_{2}$ and a high-noble alloy bonded to their corresponding porcelains. J Prosthet Dent 2008; 100(4): 274-284.

22 International Standardization Organization. Metal-ceramic bond characterization (Schwickerath crack initiation test). ISO 9693. Geneva: International Standardization Organization, 1999.

23 Bagby M, Marshall SJ, Marshall GW Jr. Metal ceramic compatibility: a review of the literature. J Prosthet Dent 1990; 63(1): 21-25.

24 de Kler M, de Jager N, Meegdes M et al. Influence of thermal expansion mismatch and fatigue loading on phase changes in porcelain veneered Y-TZP zirconia discs. J Oral Rehabil 2007; 34(11): 841-847.

This work is licensed under a Creative Commons Attribution-NonCommercial-NoDerivative Works 3.0 Unported License. To view a copy of this license, visit http:// creativecommons.org/licenses/by-nc-nd/3.0 